\title{
Prevalence of Bovine Herpesvirus- 1 in cattle and buffaloes in Punjab
}

\author{
Gurpreet Kaur, P. N. Dwivedi, Ramneek Verma and N. S. Sharma \\ College of Veterinary Science \\ Guru Angad Dev Veterinary and Animal Sciences University (GADVASU), Ludihana - 141004, Punjab, India \\ Corresponding author: Gurpreet Kaur email: gurpreet7502@rediffmail.com \\ Received: 08-10-2012, Accepted: 07-11-2012, Published online: 16-03-2013
}

\section{How to cite this article:}

Kaur G, Dwivedi PN, Verma R and Sharma NS (2013) Prevalence of Bovine Herpesvirus-1 (BHV-1) in cattle and buffaloes in Punjab, Vet. World 6(6): 343-345, doi: 10.5455/vetworld.2013.343-345

\begin{abstract}
Aim: The aim of the present study was to identify the prevalence of Bovine Herpesvirus-1 (BHV-1) in cattle and buffaloes in the Punjab using PCR as diagnostic tool.

Materials and Methods: A total of 63 samples (Semen- 57, placental cotyledons-1, vaginal secretions-1, foetal stomach contents-1 and tracheal swabs-3) from cattle and buffaloes were processed for identification of BHV-1 using PCR

Results: From January 2007 to December 2010 (Semen- 57, placental cotyledons-1, vaginal secretions-1, foetal stomach contents-1 and tracheal swabs-3) from cattle and buffaloes were collected. The DNA was extracted from a total of 63 samples and subjected to PCR revealed that none of the sample positive for the BHV-1 infection.
\end{abstract}

Conclusion: From the study it was concluded that the farms screened were free from BHV-1 infection.

Keywords: Bovine Herpesvirus-1, buffaloes, cattle, PCR, prevalence.

\section{I ntroduction}

Bovine herpesvirus type-1 (BHV-1) is a member of the family Herpesviridae, subfamily Alphaherpesvirinae. It is an important pathogen of cattle worldwide [1] and is classified as BHV-1.1 (respiratory form), BHV-1.2 (genital form) and BHV-1.3 (encephalitic form) [2]. It is responsible for great economic losses to livestock industry in terms of loss of milk production and abortion. The virus causes numerous clinical manifestations like rhinotracheitis, vulvovaginitis, balanoposthitis, abortion and encephalitis. Besides this infection, it can cause acute gastroenteritis, conjunctivititis, mastitis and repeat breeding in cattle [3]. $\mathrm{BHV}-1$ generally infects cattle greater than 6 months of age once maternal immunity has waned [4]. The virus is excreted through nasal, ocular secretion, placenta of aborted animals and through semen. In the bovine semen, BHV-1 is the most common viral pathogen and it poses a great threat to cattle industry as the virus can spread by artificial insemination causing variety of genital disorders [5]. Following an acute infection, the latent virus is established mainly in the sensory ganglia, for the rest of the life of the animal [6]. This latent virus can be reactivated and consequently excreted, with the risk of infecting herd mates which are free from BHV-1. Thus, vaccination can control the clinical disease but latent infection cannot be prevented, therefore, once cattle that have been infected must be regarded as lifelong potential shedders of BHV-1[7]. Bulls infected with BHV-1 are lifelong carriers and potentially shed virus intermittently in their semen.

Laboratory examinations are required for the diagnosis of BHV-1. Isolation of virus is the most frequent

This article is an open access article licensed under the terms of the Creative Commons Attribution License (http://creativecommons. org/licenses/by/2.0) which permits unrestricted use, distribution and reproduction in any medium, provided the work is properly cited. method for the detection of BHV-1 in the suspected clinical samples. However, this method is time consuming and laborious. The other conventional methods for detection of BHV-1, such as the fluorescent antibody test, ELISA and serological testing, lack sensitivity, particularly when applied to semen donor bulls [8]. Molecular technique such as PCR has been standardized and is commonly used to detect the presence of BHV-1 in various samples effectively because of its enhanced sensitivity, specificity and rapidity [9].Thus, in the present study clinical samples were examined with the help of PCR for the detection of BHV-1 in these animals.

\section{Materials and Methods}

Samples: A total of 63 samples including semen (57), placental cotyledons (1), vaginal secretions (1), foetal stomach contents (1) and tracheal swabs (3) from various farms, submitted in the Department of Veterinary Microbiology, College of Veterinary Science, GADVASU from January 2007 to December 2010 were processed for the BHV-1.

Sample Processesing: The frozen semen straws were thawed at $37^{\circ} \mathrm{C}$ and diluted to $1: 10$ in sterile normal saline solution and was clarified by centrifugation at $8000 \mathrm{rpm}$ for 10 minutes in a refrigerated centrifuge. The supernatant was collected and kept at $-20^{\circ} \mathrm{C}$ till further use.

The placental cotyledons and vaginal secretions were collected in phosphate buffer glycerol (PBG) and were then triturated in mortar and pestle using sterilized sand and normal saline solution. It was then clarified by centrifugation at $8000 \mathrm{rpm}$ for 10 minutes in refrigerated centrifuge. The supernatant was also collected and stored at $-20^{\circ} \mathrm{C}$ till further use.

The foetal stomach content was diluted 1:10 in phosphate buffer saline and then clarified by centrifugation at $8000 \mathrm{rpm}$ for 10 minutes in refrigerated centrifuge. The 
Table-1. Total number of samples tested via PCR for the detection of BHV-1

\begin{tabular}{llc}
\hline Sr. No. Sample & PCR (Positive/Total) \\
\hline 1. & Semen sample (33 Cattle; 24 Buffaloes) & $0 / 57$ \\
2. & Placental Cotyledons (Buffalo) & $0 / 1$ \\
3. & Vaginal Secretion (Cow) & $0 / 1$ \\
4. & Foetal Stomach Contents (Buffalo) & $0 / 1$ \\
5. & Tracheal Swab (Buffalo) & $0 / 3$ \\
\hline
\end{tabular}

supernatant was collected and stored at $-20^{\circ} \mathrm{C}$ till further use.

The tracheal swab was collected in a test-tube having $2 \mathrm{ml}$ of sterilized tryptose phosphate broth. It was centrifuged at $8000 \mathrm{rpm}$ for 10 minutes. The supernatant was collected and stored at $-20^{\circ} \mathrm{C}$ till further use.

I solation of DNA: The total DNA was extracted from $600 \mu$ l of the each of the above processesed sample. In brief, twenty microlitres of proteinaseK $(20 \mathrm{mg} / \mathrm{ml})$ and of $10 \%$ SDS was added, mixed by vortex for 15 seconds and incubated at $56^{\circ} \mathrm{C}$ for 2 hours. Subsequently, equal volume of phenol: chloroform: isoamyl alcohol $(25: 24: 1)$ was added to the above solution. It was vortexed for 15 seconds and then centrifuged at $13000 \mathrm{rpm}$ for 15 minutes. To the supernatant equal volume of chloroform: isoamyl alcohol (24:1) was added, mixed gently and centrifuged at $13000 \mathrm{rpm}$ for 15 minutes. To the supernatant, $1 / 10$ volume of $3 \mathrm{M}$ sodium acetate solution ( $\mathrm{pH}$ 5.2) and equal volume of isopropanol was added and stored at $-20^{\circ} \mathrm{C}$ overnight to allow precipitation of DNA. DNA was pelleted by centrifugation at $12000 \mathrm{rpm}$ for 10 minutes at $4^{\circ} \mathrm{C}$. The pellet was then washed with $70 \%$ ethanol twice, air dried and resuspended in $50 \mu \mathrm{l}$ of Tris-EDTA buffer ( $\mathrm{pH} \mathrm{8.0)}$ and stored at $-20^{\circ} \mathrm{C}$ till further use.

Polymerase chain reaction (PCR): For the PCR, Forward primer 5'CACGGACCTGGTGGACAAGAAG3' and Reverse primer 5'CTACCGTCACGTGAGTGGTACG3' as reported by Vilcek [10] was used in the present study. The reaction mixture for the PCR included $10 \mu \mathrm{l}$ of template DNA, $1.0 \mu \mathrm{l}$ of forward and reverse primers $(10 \mathrm{pm} / \mu \mathrm{l})$ each,

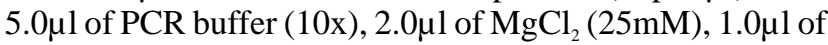
dNTPs (10mM each), $0.2 \mu l$ of Taq Polymerase (5units/ $\mu \mathrm{l}$ ) and $29.8 \mu \mathrm{l}$ of nuclease free water to make the final reaction volume to $50 \mu 1$.

The PCR conditions included an initial denaturation at $95^{\circ} \mathrm{C}$ for 3 minutes and then 35 cycles of denaturation at $95^{\circ} \mathrm{C}$ for 60 seconds, annealing at $55^{\circ} \mathrm{C}$ for 60 seconds and extension at $75^{\circ} \mathrm{C}$ for 60 seconds and then a final extension at $72^{\circ} \mathrm{C}$ for 10 minutes. The PCR products were analyzed using $1 \%$ agarose gel with $0.05 \mathrm{ug} / \mu \mathrm{l}$ ethidium bromide. It was electrophoresed at 5-10 volts/cm for 1 hour. Gene Ruler ladder plus 100 bp (MBI, Fermentas) was run for calculating the relative molecular weight.

In the PCR BHV-1 isolate (IBR 216 II batch No. 9/98), obtained from IVRI, Izatnagar available in the Department of Veterinary Microbiology, Ludhiana was used as positive control in the study.

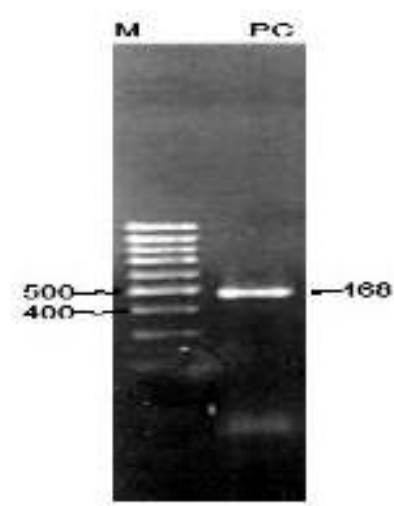

Figure-1. PCR exhibiting a product in a known positive sample ( $M$ : Marker; PC: Positive Control)

\section{Results and Discussion}

Infectious bovine rhinotracheitis (IBR) is a highly contagious disease caused by BHV-1 affecting cattle and buffaloes [11] and it is present worldwide. BHV-1 infects respiratory and genital tracts of cattle and buffaloes causing various diseases. PCR is an invaluable tool for detection of BHV-1 particularly from clinical samples [12,13,14]. The greatest problem with the infections caused by herpes virus is the induction of carrier state in the animals, due to which, the presence of antibodies in an animal does not indicate the true picture of active infection. Considering this major drawback in serum based tests, detection of virus becomes mandatory to designate an animal as positive for BHV-1 [15]. Out of a total of 63 samples tested in the present study, none of the samples was positive when tested with PCR (Table-1). The reference DNA used in the study showed positive amplification of $468 \mathrm{bp}$ in PCR suggests that the assay used was specific and sensitive for BHV-1 and could be used to detect BHV-1 in different samples from infected animals (Fig. 1). In an earlier study conducted in 1998 in the Lusaka province of Zambia, the prevalence of BHV-1 antibodies in bovine sera was reported to be in between $0 \%$ to $80 \%$ [16]. In another study, two polymerase chain reaction assays specific for glycoprotein B (gB) and glycoprotein C (gC) gene detection were used for the detection of bovine herpesvirus- 1 in naturally infected cattle and reported that out of 12 bovine tissue samples tested for $\mathrm{gB}$ and $\mathrm{gC}$ only one sample was found to be positive for presence of viral genome, producing an amplified PCR product of size $173 \mathrm{bp}$ [17].

PCR was used in another study for the detection of BHV-1 directly from semen samples and it was reported that PCR failed to amplify in some of the semen samples which was attributed due to the inhibitory effect of the bovine semen [18]. However, it was also reported that by using a purification protocol that eliminated the interfering components, the sensitivity of PCR increased markedly [19]. Out of a total of 523 semen samples collected and screened by isolation of virus for BHV-1 in bovine turbinate (BT) and Mardin Darby Bovine Kidney (MDBK) cell lines from the four southern states of India revealed that, only four semen samples showed cytopathic changes indicating that the prevalence of BHV-1 is scarce [20] similar to our findings in which we too failed in detecting BHV-1. Similarly in another study, the prevalence of BHV-1 was found to be $0.8 \%$ (2/250) [21]. However, in a study on 574 semen samples from seropositive cattle and buffaloes tested by real time PCR indicated that $1.97 \%$ cattle and $3.36 \%$ buffalo semen 
batches were positive for BHV-1 indicating that real time PCR in adjunct could be used in diagnostic laboratories for identifying BHV-1[22].

\section{Conclusion}

It could be concluded that none of the animals screened using PCR, yielded positive results indicating that the farms screened were free from BHV-1 infection. The finding assumes significance as far as farm management is concerned because BHV-1 infection in farm is deleterious and if established cannot be eradicated easily since virus hides in the ganglions of the affected animals and persists for the lifetime in the host.

\section{Authors' contribution}

GK designed the study. GK, RV and PND conducted the experiment and analyzed the data. GK and NSS drafted and revised the manuscript. All authors read and approved the final manuscript.

\section{Acknowledgements}

The authors are thankful to Director of Research, GADVAS University and Head, Department of Veterinary Microbiology, for providing the facilities for the smooth conduct of the study. The authors are also thankful to Mudit Chandra for his help in the manuscript revision.

\section{Competing interests}

Authors declare that they have no competing interests.

\section{References}

1. Woodbine K. A., Medley G. F., Moore S. J., RamirezVillaescusa A. M., Mason S. and Green L. E. (2009) A four year longitudinal sero-epidemiological study of bovine herpesvirus type-1 (BHV-1) in adult cattle in 107 unvaccinated herds in south west England, BMC Vet. Res., 5:5.

2. Studdert M. Z. (1989) Bovine encephalitis Herpesvirus, Vet. Rec., 125: 584.

3. Ata A., Kocamuftuoglu M., Hasiroioglu S. and Kale M. (2008) Investigation of bovine herpesvirus-1 (BHV-1) infection in relation to fertility in repeat breeder cows. In: Proceedings of the 16 th congress of the Mediterranean federation for health and production of ruminants April 26, Zadar, Croatia pp: 63-69.

4. Bennett R. and Ijpelaar J. (2003) Economic Assessment of Livestock Diseases in Great Britain, Final Report of DEFRA, the University of Reading.

5. Elazhary M.A.S.Y., Lamothe P., Silim A. and Roy R.S. (1980) Bovine Herpesvirus type 1 in the sperm of a bull from a herd with fertility problems, Can. Vet. J., 21:336-339.

6. OIE (2010) Manual of Diagnostic tests and vaccines for terrestrial animals. OIE, Paris, France.

7. Kaashoek M.J., Moerman A., Madic J., Rijsewijk F.A.M., Quak J., Gielkens A.L.J. and van Oirschot J.T. (1994) A conventionally attenuated glycoprotein E-negative strain of bovine herpesvirus type 1 is an efficacious and safe vaccine, Vaccine, 12(5): 439-444.

8. Zhou J., Lyaku J., Fredrickson R.A. and Kibenge F.S.B. (1999) Improved detection of bovine herpesvirus 1 in artificially infected bovine semen by protein amplification, J. Virol. Meth., 79 (2): 181-189.

9. Mahmoud M. A. and Ahmed S. A. (2009) Prevalence of bovine herpesvirus-1 (BHV-1) in sheep and goats in Egypt. Global Veterinaria, 3: 472-479.

10. Vilcek S. (1993) Detection of bovine herpesvirus-1 BHV-1 genome by PCR, J. Virolog. Meth., 41: 245-247.

11. Rola J., larska M. and Polak M. P. (2005) Detection of Bovine herpesvirus 1 from an outbreak of Infectious Bovine Rhinotracheitis, Bull. Vet. Inst. Pulaway., 49: 267-271.

12. Rocha M. A., Barbosa E. F., Guedes R.M.C., Lage A. P., Leite R. C. and Gouveia A. M. G. (1999) Detection of BHV1 in a naturally infected bovine fetus by a nested PCR assay, Vet. Res. Commun., 23: 133-141.

13. Santurde G., Silva N. Da., Villare R., Tabares E., Solana A., Bautista J. M., Castro J.M. and Da-Silva N. (1996) Rapid and high sensitivity test for the direct detection of bovine herpesvirus-1 genome in clinical samples, Vet. Microbiol., 49: 81-92.

14. Vilcek S., Nettleton P. F., Herring J. A. and Herring A. J. (1994) Rapid detection of bovine herpesvirus-1 (BHV-1) using the polymerase chain reaction, Vet. Microbiol., 42: 5364.

15. Anonymous. (2008) Manual of Diagnostic Tests and Vaccines for Terrestrial Animals. Chapter 2.4.13. Infectious Bovine Rhinotracheitis. pp. 752-763.

16. Mweene A.S., Fukushi H., Pandey G.S., Syakalima M., Simuunza M., Malamo M., Nambota A., Samui K.L.,Tsubota T., Nakazato Y., Onuma M. and Yasuda J. (2003) The prevalence of bovine herpesvirus-1 in traditional cattle in Southern Province, Zambia, Rev. sci. tech. Off. Int. Epiz., 22 (3): 873-877.

17. Anita D., Anita A. and Savuta G. (2010) Detection of Bovine Herpesvirus Type 1 by PCR Assay, Bulletin UASVM, Vet.Med., 67(2): 23-27.

18. Deka D., Ramneek, Maiti N.K. and Oberoi M.S. (2005) Detection of bovine herpesvirus-1 infection in breeding bull semen by virus isolation and polymerase chain reaction, Rev. sci.tech. Off. Int. Epiz., 24 (3): 1085-1094.

19. Engelenburg F.A.C. van, Maes R.K., Oirschot J.T. van and Rijsewijk F.A.M. (1993) Development of a rapid and sensitive polymerase chain reaction assay for detection of bovine herpesvirus type 1 in bovine semen, J. Clin. Microbiol., 31 (12):3129-3135.

20. Chandranaik B.M., Chethana, Shivraj, Kumar S. and Renukaprasad C. (2010) Isolation of BHV-1 from bovine semen and application of real time PCR for diagnosis of IBR/IPV from clinical samples, Veterinarski Arhiv., 80 (4): 467-475.

21. Iscan U.T. and Duman R. (2011) Bovine Herpesvirus Type1 (BHV-1) Prevalence in Dairy cattle. JAVA., 10(12): 15231525.

22. Rana S.K., Kota S.N.L.S., Samayam P.N.R., Rajan S. and Srinivasan V.A. (2011) Use of real time polymerase chain reaction to detect bovine herpesvirus-1 in frozen buffalo and cattle semen in India, Veterinaria Italiana, 47(3):313-322. 